\title{
Study of non-metric characters of the skull to determine the epigenetic variability in populations of the European wildcat (Felis silvestris silvestris) and domestic cats (Felis catus)
}

\author{
Lisa Lehmann ${ }^{1} \cdot$ Clara Stefen $^{1}$ (D)
}

Received: 28 August 2020 / Accepted: 10 March 2021 / Published online: 16 April 2021

(c) The Author(s) 2021

\begin{abstract}
We studied the variability of non-metric cranial traits, mainly foramina, of European wildcats (Felis silvestris silvestris) and domestic cats (Felis catus) from Germany based on 28 non-metric traits in 211 skulls. The domestic cats were grouped together as a statistical population. The wildcats were divided into two populations: Harz and Hesse, which were further subdivided, based on traffic infrastructure, natural landscape, and in the Harz, on time period. Epigenetic variability, epigenetic distance and the fluctuating asymmetry were calculated to assess genetic variability, possible depressions and population stability. The epigenetic variability $I_{\mathrm{ev}}$ of the wildcat groups ranged from 0.27 (Hesse II) to 0.40 (Harz I). The difference in $I_{\mathrm{ev}}$ between all specimens from Harz and Hesse respectively was less $\left(I_{\mathrm{ev}}=0.37 \mathrm{Harz}\right.$ and 0.31 Hesse). Compared to other studies these values are not assumed to indicate genetic depression. The epigenetic distance between the wildcat samples is 0.0774 overall, and in each case higher between sub-groups of the Harz and Hesse than between groups within these regions, respectively. The significant epigenetic distance between Harz and Hesse might indicate—at least past formerly—restricted connectivity between these regions. The fluctuating asymmetry for wildcats in total is $11.74 \%$ and in the sub-groups it ranges from 8.47 to $16.14 \%$. These values are below $20 \%$ are at the lower range known from populations of other mammal species. The use of fluctuating asymmetry had also been discussed critically in its usefulness to assess viability of populations.
\end{abstract}

Keywords Epigenetic distance $\cdot$ Fluctuating asymmetry $\cdot$ Craniological foramina $\cdot$ Germany $\cdot$ Harz $\cdot$ Hesse

\section{Introduction}

Morphological studies of the skull and skeleton yield information about the characteristics of a species, show postnatal ontogenetic changes, as well as variability in adults differing between populations within and across species representing phenotypic biodiversity. Often morphometric and increasingly geometric morphology methods are used to describe and potentially distinguish populations and/or closely related species. But, also minor non-metric skeletal features, often called 'epigenetic' traits (Corruccini 1976), are variable

Handling editor: Gabriele Sansalone.

Clara Stefen

Clara.stefen@senckenberg.de; cmstefen@web.de

Lisa Lehmann

lisalehmann93@web.de

1 Senckenberg Naturhistorische Sammlungen Dresden, Königsbrücker Landstraße 159, 01109 Dresden, Germany and are used to assess diversity of populations and species. The basic principles to study the variability in non-metric characters as indicators of genetic variability in mammals have been reviewed by Ansorge (2001). This research was mainly developed and established in the middle of the last century. At this time the heritability of non-metric traits in men and rodents were studied, for example, by Grünberg (1952), Berry (1963), Berry and Berry (1967) and Hilborn (1974). Even prior to these studies research dealt with the inheritance of dental characters in human twins, like Korkhaus (1930). Particularly Berry (1963) and Berry and Searle (1963) laid the basis for the current use and terminology in this field. They coined the term 'epigenetic polymorphism' to distinguish the variation in non-metric traits from true genetic polymorphism (Berry and Searle 1963). Thus, epigenetic variability refers to non-metric differences in the expression of morphological characters.

Differences in non-metric characters are a type of discontinuous variation. These characters are under basic genetic control but the discontinuity is due to developmental 
influences (Berry and Searle 1963). The basic genetic control and the general independence of growth render them suitable to assess the genetic variability behind them (Bauchau 1988). Sjøvold (1977) developed some basic methods in this field of non-metric variability to determine epigenetic variability and distance.

The use of non-metric traits and particularly the diversity observed in the specificity or expression of the traits, the 'epigenetic variability' was established as indicator for population genetics. Similarly, the analysis of fluctuating asymmetry of non-metric traits was used as measure of developmental stability (Ansorge 2001). As non-metric or epigenetic traits are easy to scan in museum collections, are generally assumed to be neither dependent on sex and age nor intercorrelated (Corruccini 1976) their use became attractive to assess the population status of species (Ansorge and Stubbe 1995; Ansorge et al. 2009, 2012; Lkhagvasuren et al. 2015; Ranyuk and Monakhov 2016). Specifically endangered species were examined to identify genetic impoverishment in populations (Pertoldi et al. 1998; Usukhjargal et al. 2020; Wiig and Bachmann 2014).

The wildcat (Felis silvestris Schreber, 1777) has a palaearctic distribution from Scotland to South Africa and from Morocco to South China (Driscoll et al. 2007), when the three groups silvestris (European wildcat), lybica (African wildcat) and ornata group (Asian or Indian wildcat) are understood to be subspecies (Kitchener 1991; Wozencraft 1993). More recently these are considered as separate species, which leaves a smaller geographic range for Felis silvestris with the subspecies $F$. s. silvestris from (Central) Europe, but now includes Scotland, Sicily and Crete, $F$. $s$. grampia originally from Scotland but probably extinct and F. s. caucasica from the Caucasus and Turkey (Kitchener et al. 2017). The domestic cat (Felis catus Linnaeus 1758) probably originated from the African wildcat and was distributed around the world by humans (Serpell 1988; CluttonBrok 1999; Driscoll et al. 2009). The European wildcat ( $F$. s. silvestris) is under special protection in Europe due to the Habitat Directive (Council Directive 92/43/EEC) adopted in 1992 by the European Union. For the reports to the EU on protected species under the Habitat Directive, studies on occurrence, conservation and management are necessary, but also the assessment of the diversity (morphological and genetic) and genetic viability of populations of the species are required. This diversity is mainly addressed using molecular tools (e. g., Steyer et al. 2016). However, so far non-metric traits have not been used to assess the population viability.

Therefore, here, we study non-metric traits of the skull to evaluate epigenetic variability as an indicator of genetic diversity and thus population viability and health of wildcats in Germany, particularly in the Harz and in Hesse. Fluctuating asymmetry is used as measure of developmental stability according to Ansorge (2001). We also shed light on the question if wild and domestic cats might be differentiated by the use of non-metric traits, i.e., differences in the frequency of the specificity of some traits.

\section{Materials and methods}

\section{Materials and study areas}

In total, skulls of 71 domestic cats and 140 wildcats were examined (full list see Supplementary Material Table S1). The cats are housed in the following collections: the Senckenberg Museum für Tierkunde Dresden, the Central Repository for Natural Science Collections Department at Martin-Luther-Universität Halle-Wittenberg, the Senckenberg Museum of Natural History Görlitz, the Vonderau Museum in Fulda. The loan from the latter included two domestic cats from the Phylogenetische Museum in Jena. The animals date from 1878 to 2018 . The determination of the cats was based on cranial volume and other morphological features and several are included in Stefen and Heidecke (2011). Those from the Vorderau Museum were determined by F. Müller.

The domestic cats come from all over Germany and were grouped together as one statistical population. The wildcats were divided into two populations: from the Harz and Hesse with foothills to Lower Saxony, Rhineland-Palatinate and Bavaria (Fig. 1). In addition, these two wildcat populations were subdivided each into two groups to identify possible differences within the populations. The division was made (a) on regional level using large traffic infrastructure which might be transversed by migrating wildcats and (b) on temporal scale using time periods. The A7 motorway was chosen to separate the Hesse population and the federal highway B81 for the Harz population. Additionally, the populations could be divided into two sub-samples based on the classification of natural landscapes. In the Harz, one group is limited to the 'östliche Harzabdachung' (Harz $\mathrm{nl}_{1}$ ) and the second group includes all individuals northwest of it (Harz $\mathrm{nl}_{2}$ ). In the Hesse population, one group occurs on the Hessian Franconian highlands and the East Hessian highlands (Hesse $\mathrm{nl}_{1}$ ), while the other group covers the natural areas west of it $\left(\right.$ Hesse $\left.\mathrm{nl}_{2}\right)$. In Hesse, however, this division corresponds to the grouping using the A7, except for few individuals, so that this subgrouping was not treated separately. A subdivision on the temporal scale was only made for the Harz population in the periods $1942-1980$ and 1981-2018 (Harz $t_{1}$ and $t_{2}$ respectively). The specimens from Hesse date from a period too short for a comparable subdivision (1993-2018). 
Fig. 1 Overview map of the localities of the examined wildcat skulls. The major German motorways are given (after https://de.wikipedia.org/ wiki/Datei:Deutschland_Autob ahnen_Master.svg, the list of motorways can be found at https://de.wikipedia.org/wiki/ Liste_der_Bundesautobahnen_ in_Deutschland), A7 and A5 are labeled. For the groups Harz and Hesse the sub-samples are indicated. According to traffic structures: Hesse I (black) and Hesse II (grey), east and west of A7; Harz I (black) and Harz II (grey) separated by the federal highway B81 (not shown)

(a). The Harz group was also separated according to natural landscape (b): Harz $\mathrm{nl}_{1}$ of the western Harz, and Harz $\mathrm{nl}_{2}$ (black) of the 'östliche Harzabdachung' (grey)

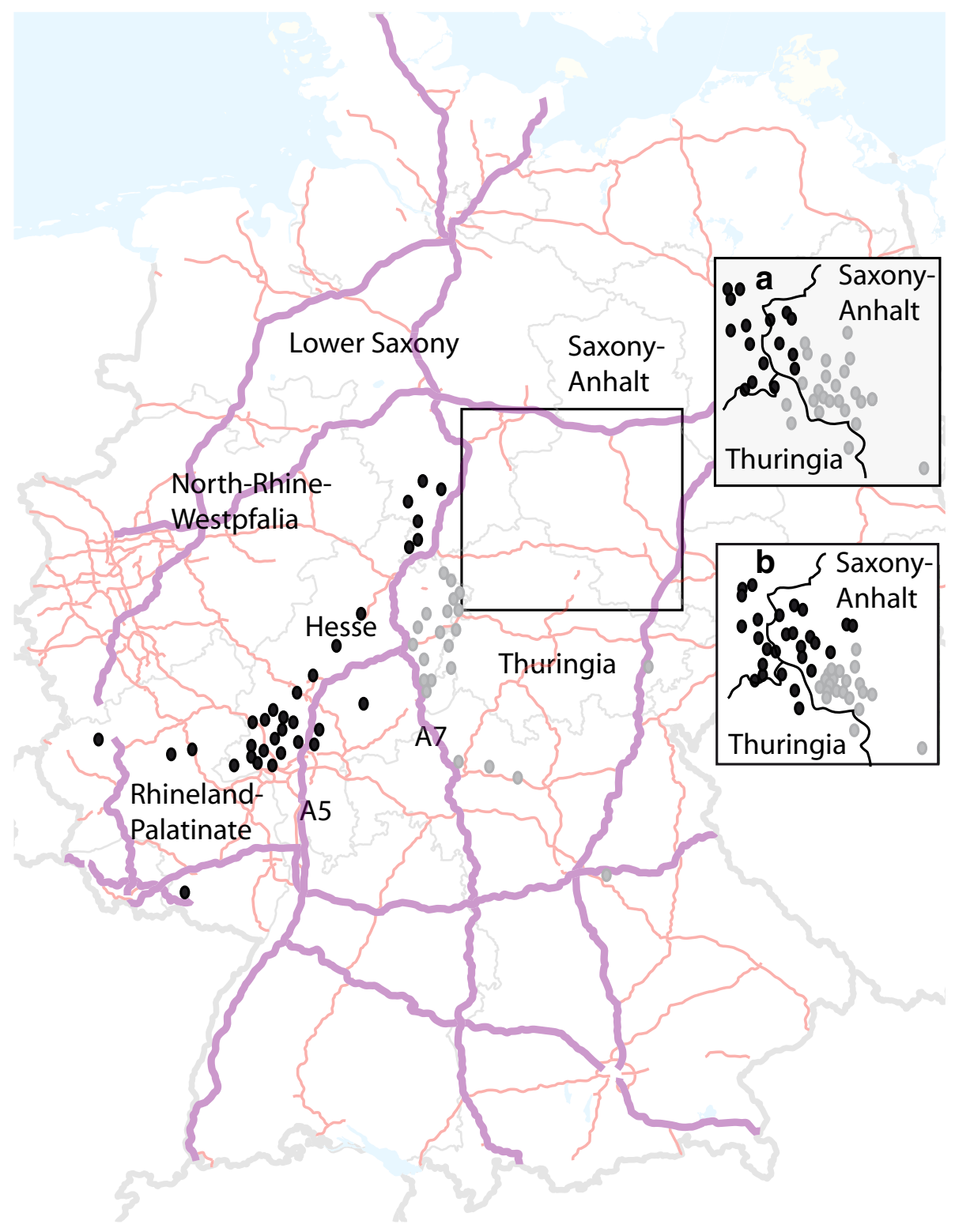

\section{Methods}

The basic principles in use and statistical analysis of nonmetric traits were developed in the 1960s as is briefly outlined above. In this study, an epigenetic and thus non-metric analysis of collected skulls from museums was performed. This qualitative analysis is often used to detect and assess diversity and potential differentiations between populations or taxa. Usually characters of the skeleton are selected for study that are not directly conditioned by environmental influences and are assumed to be independent of ontogeny. Often skulls are used as they are under many constraints, are well studied and usually available in collections. Foramina are openings in the bone for nerves and/or blood vessels. The question generally posed is whether a certain foramen is present or not, or whether it is expressed single, double or even multiple. The presence of the non-metric characters traits is under basic genetic control and, therefore, the determination of epigenetic differences between groups enables an assessment of the basic genetic variability of the groups. (Berry 1975; Sjøvold 1977). The traits are assumed to be independent of age and sex.

A total of 28 non-metric characters of skull and mandible were selected for this study (Table 1; Fig. 2). Five characteristics were examined bilaterally on the mandible, twenty-two, again bilaterally, on the cranium, and one unilaterally on the cranium. The non-metric characteristics were selected partly on the basis of previous epigenetic studies of other carnivores (Sjøvold 1977; Wiig and Lie 1979; Wiig and Andersen 1988; Ansorge and Stubbe 1992, 
Table 1 Non-metric traits on the skull of the wild and domestic cat

\begin{tabular}{|c|c|}
\hline No & Trait \\
\hline 1 & Additional small foramen anterior to Foramen incisivum \\
\hline 2 & Foramen maxillare I dorsal to the first premolar \\
\hline 3 & Foramen palatinum minus present \\
\hline 4 & Foramen nasale I present \\
\hline 5 & Foramen nasale II present \\
\hline 6 & Foramen maxillare II above the Foramen infraorbitale present \\
\hline 7 & Foramen maxillare III present along the suture between Maxilla and Os incisivum \\
\hline 8 & Foramen praemaxillare present \\
\hline 9 & Foramen maxillare posterior present \\
\hline 10 & Foramen postorbitale posterior present \\
\hline 11 & Foramen zygomaticum present \\
\hline 12 & Fenestra occipitalis present as a non-ossified area above the Foramen magnum \\
\hline 13 & Canalis condylaris double \\
\hline 14 & additional small foramen on the Canalis nervi hypoglossi \\
\hline 15 & Foramen postglenoidalis present \\
\hline 16 & Foramen alisphenoidalis ventralis double \\
\hline 17 & Additional small foramen dorsal to the Foramen opticum \\
\hline 18 & Additional small foramen dorsal to the Foramen rotundum I \\
\hline 19 & Additional small foramen next to the Foramen rotundum II \\
\hline 20 & Additional small foramen posterior to behind the Foramen ovale \\
\hline 21 & Foramen postorbitale present \\
\hline 22 & First upper premolar missing \\
\hline 23 & Foramen mentale posterior double \\
\hline 24 & Foramen mentale anterior single \\
\hline 25 & Foramen angularis present \\
\hline 26 & Foramen mandibulare anterior multiple \\
\hline 27 & Foramen coronoidale present \\
\hline 28 & Additional foramen ventral to or next to the Foramen infraorbitale \\
\hline
\end{tabular}

1995; Ansorge et al. 2009) and our own considerations. First, foramina that were well visible or studied in other Carnivora like Lynx (Wiig and Andersen 1988) or Lutra (Ansorge and Stubbe 1992; Ranyuk and Ansorge 2015) were searched in Felis and the expression was checked in ten domestic and ten wildcats. Second, in case the expression was the same in all 20 specimens, the foramen was not considered further. Only if there were some differences, the foramen was checked in all examined skulls for being single, double, multiple or lacking.

The $\chi^{2}$-test at a significance level of $p<0.05$ (Weber 1980) was used to check for differences in the frequency of the characteristic expression. It also served to ensure homogeneity in the distribution by age and sex. After the age- and sex-dependent foramina were eliminated, the epigenetic variability $\left(I_{\mathrm{ev}}\right)$, the epigenetic distance (MMD) and the fluctuating asymmetry (FA) could be calculated based on the remaining foramina.

According to Smith (1981), the degree of epigenetic variability $I_{\mathrm{ev}}$ for the entire population is calculated as follows:
$I_{\mathrm{ev}}=I-\frac{\sum_{i=1}^{n}\left|50 \%-F_{i}\right|}{r * 50 \%}$

where $r=$ number of traits; $F_{i}=$ frequency of the respective feature.

The degree of epigenetic distance between the groups was determined using the mean measure of divergence (MMD) and a formula proposed by Sjøvold (1977). Finally, 20 independent characters were used.

$\mathrm{MMD}=\frac{1}{r} \sum_{i=1}^{r}\left(\Theta_{1 i}-\Theta_{2 i}\right)^{2}-v_{i}$

where $r=$ number of traits; $n=$ sample size; $p=$ frequency of traits; $\Theta=\arccos (1-2 p) ; v_{i}=n_{1}^{-1} n_{2}^{-1}$.

The statistical significance of MMD is calculated on the basis of the standard deviation of MMD, the SMMD:

$s_{\mathrm{MMD}}=\sqrt{\frac{2 \sum_{i=1}^{r} v_{i}^{2}}{r^{2}}}$. 

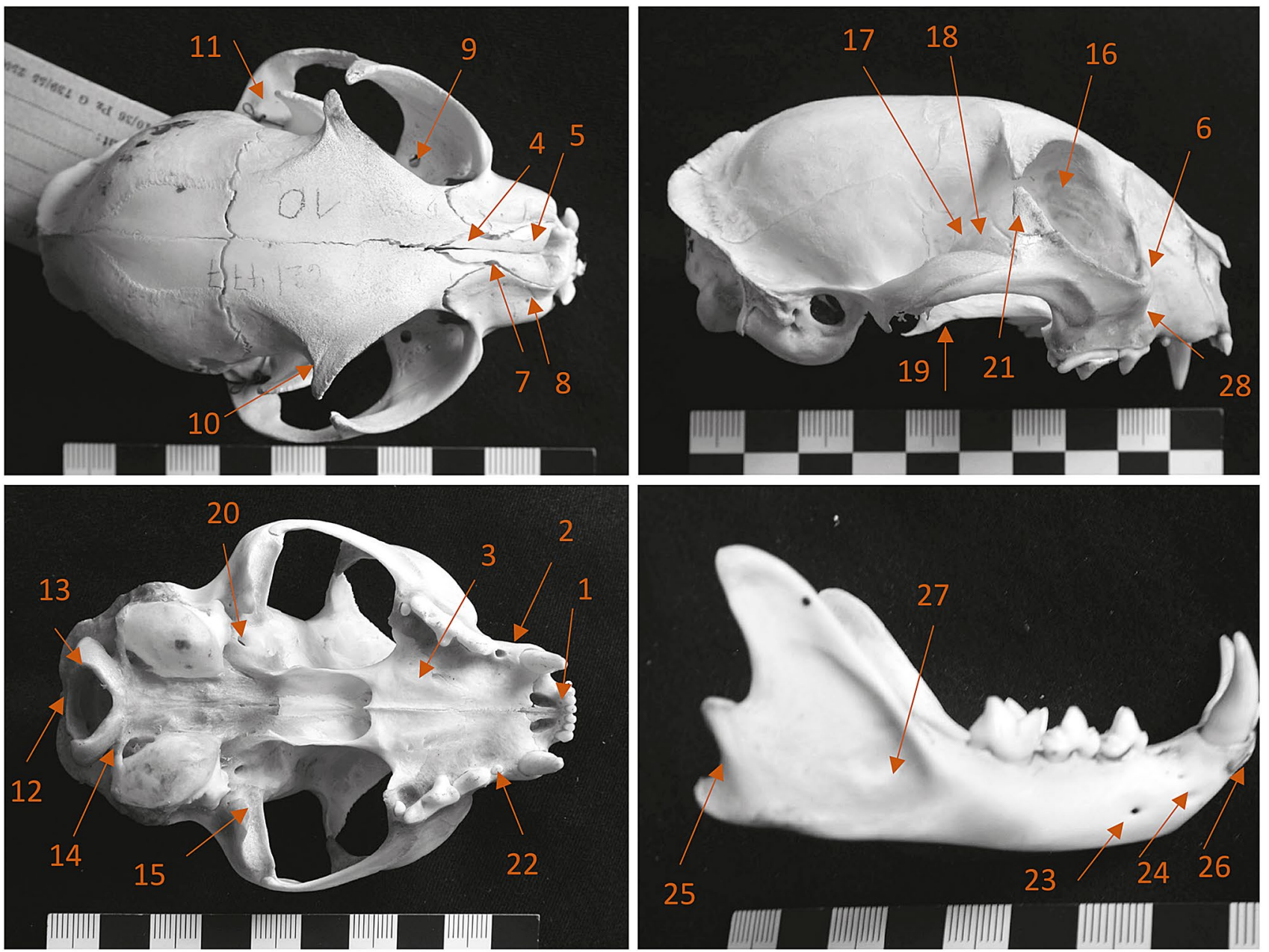

Fig. 2 Non-metric traits selected for the study on the skull and mandible of the wild and domestic cat in dorsal, lateral and ventral view and lateral view of the mandible. The corresponding legend is found in Table 1. The basic figure of skulls is from Stefen and Heidecke (2012)

Statistical significance is given if MMD $>2 *$ SMMD $(p=0.05)$ according to Sjøvold (1977).

The relation of the number of asymmetric occurrences of a single character to the overall sample size defines the fluctuating asymmetry (FA). The unscaled mean for all characters gives the degree of asymmetry in the population (Palmer and Strobeck 1986, 2003; Ansorge et al. 2012). A low degree of asymmetry indicates high fitness and stability and vice versa a high degree of asymmetry a low stability (e.g., Swaddle et al. 1994). This allows conclusions to be drawn about the developmental stability of a population.

Microsoft Office Excel 2007 and the software package AnthropMMD from the program R (version 3.6.1) developed by Santos (2018) were used for the calculation.

\section{Results}

Of the 28 characteristics examined, four foramina showed a statistically significant correlation to sex (trait number $6,9,25,27)$ and another four to age (\# 3, 14, 24, 26; see Table 1). Thus, these eight were eliminated from further analyses.

\section{Epigenetic variability}

The epigenetic variability of the two wildcat populations Harz and Hesse differ with $0.06\left(I_{\mathrm{ev}}=0.37\right.$ and 0.31 , 
Table 2 Epigenetic variability $I_{\mathrm{ev}}$ of the studied wildcat populations from the Harz and Hesse as well as their sub-samples according to traffic infrastructure, time periods and natural landscapes and domestic cats

\begin{tabular}{llcc}
\hline Population & Subdivision & $\begin{array}{c}\text { Number of } \\
\text { individuals }\end{array}$ & $I_{\mathrm{ev}}$ \\
\hline Harz & & 76 & 0.37 \\
Hesse & & 64 & 0.31 \\
Total wildcats & & 140 & 0.36 \\
Domestic cats & & 71 & 0.48 \\
Harz I & West of B81 & 26 & 0.40 \\
Harz II & East of B81 & 50 & 0.35 \\
Hesse I & West of A7 & 41 & 0.32 \\
Hesse II & East of A7 & 23 & 0.27 \\
Harz t & 1942-1980 & 32 & 0.37 \\
Harz t & 1981-2018 & 44 & 0.36 \\
Harz $\mathrm{nl}_{1}$ & östliche Harzabdachung & 34 & 0.34 \\
Harz $\mathrm{nl}_{2}$ & Western Harz & 42 & 0.40 \\
\hline
\end{tabular}

$B 81$ federal highway, $A 7$ federal motorway

Table 3 The degree of epigenetic distance between the mentioned grouped indicated by the mean measure of divergence (MMD); the MMD values of non-metric skull features of the given wildcat populations to each other and to the studied domestic cats calculated with AnthropMMD

\begin{tabular}{lll}
\hline & Hesse & domestic cats \\
\hline Harz & $0.0774^{*}$ & $0.1513^{*}$ \\
Hesse & & $0.2194^{*}$ \\
Total wildcats & & $0.1597^{*}$ \\
\hline
\end{tabular}

*Statistically significant

respectively), and in both as well as combined $\left(I_{\mathrm{ev}}=0.36\right)$ is lower than in the studied domestic cats $\left(I_{\mathrm{ev}}=0.48\right)$. (Table 2) The epigenetic variability of the sub-samples Hesse I and II, as well as Harz I and II differ by 0.05. All determined $I_{\mathrm{ev}}$ are in a similar range from 0.31 to 0.40 , but one, of the group Hesse II east of the A7, is lower $\left(I_{\mathrm{ev}}=0.27\right)$. The sub-groups of the Harz divided on the basis of natural landscape show a slight difference in the epigenetic variability, whereas the samples based on collection date have a very similar $I_{\mathrm{ev}}$ (Table 2).

\section{Epigenetic distance}

The epigenetic distance between the groups of wildcats from Hesse and Harz is statistically significant. But between the sub-groups divided by traffic infrastructure (Harz I and II and Hesse I and II, respectively) and between Harz $\mathrm{nl}_{1}$ and Harz $\mathrm{nl}_{2}$ there are no significant differences (Tables 3, 4, 5). There is a significant difference in MMD between the wildcats from Harz and Hesse, as well as between the sub-groups
Table 4 The degree of epigenetic distance between the mentioned grouped indicated by the mean measure of divergence (MMD); MMD values of non-metric skull features of the named wildcat subpopulations grouped by traffic arteries and domestic cats, calculated with AnthropMMD

\begin{tabular}{lllll}
\hline & Harz II & Hesse I & Hesse II & Domestic cats \\
\hline Harz I & -0.0032 & $0.1034^{*}$ & $0.1144^{*}$ & $0.0938^{*}$ \\
Harz II & & $0.0543^{*}$ & $0.0788^{*}$ & $0.1778^{*}$ \\
Hesse I & & & 0.0243 & $0.1772^{*}$ \\
Hesse II & & & & $0.2905^{*}$ \\
\hline
\end{tabular}

*Significant

Table 5 The degree of epigenetic distance between the mentioned grouped indicated by the mean measure of divergence (MMD); MMD values of non-metric skull features of wildcat populations grouped by the classification of natural landscape, calculated with AnthropMMD

\begin{tabular}{lllll}
\hline & Harz nl2 & Hesse I & Hesse II & Domestic cats \\
\hline Harz nl1 & -0.0139 & $0.0557^{*}$ & $0.0699 *$ & $0.1648^{*}$ \\
Harz nl2 & & $0.0843^{*}$ & $0.1078^{*}$ & $0.1169 *$ \\
\hline
\end{tabular}

*Significant

Hesse I and II to Harz I and II. In addition, there is a significant difference between all examined wildcat samples and the domestic cats (Fig. 3). The MMD between the groups Harz $\mathrm{t}_{1}$ and Harz $\mathrm{t}_{2}$ is 0.0106 and, therefore, not significant.

\section{Fluctuating asymmetry}

The FA of all the studied wildcats, $11.74 \%$, is clearly below the FA of the domestic cats with $19.04 \%$ (Table 6). In the wildcats from Hesse in total as well as in the sub-samples, the FA is smaller than in the Harz wildcats again in all sub-groupings.

\section{Discussion}

The relatively simple method to study the variability in non-metric skeletal characteristics-often focused on cranial foramina- has been established as indicator of genetic variability (Ansorge 2001) and thus ultimately of viability of populations or samples (temporal or geographic). Specially endangered species were examined to identify genetic depletion such as inbreeding or bottleneck effects in the populations (Ansorge and Stubbe 1995; Pertoldi et al. 1998; Wiig and Bachmann 2014; Lkhagvasuren et al. 2015). Additionally, it can be used to assess the divergence and distance between populations. (Ansorge 2001) The prerequisite for such studies is a high number of non-metric characters. This was given here by the use of 28 foramina, which is in the 
Fig. 3 Dendrogram of the epigenetic distances of the subpopulations grouped by traffic infrastructure based on the MMD values ( $x$-axis) in Table 4

\section{Dendrogram of sub samples}

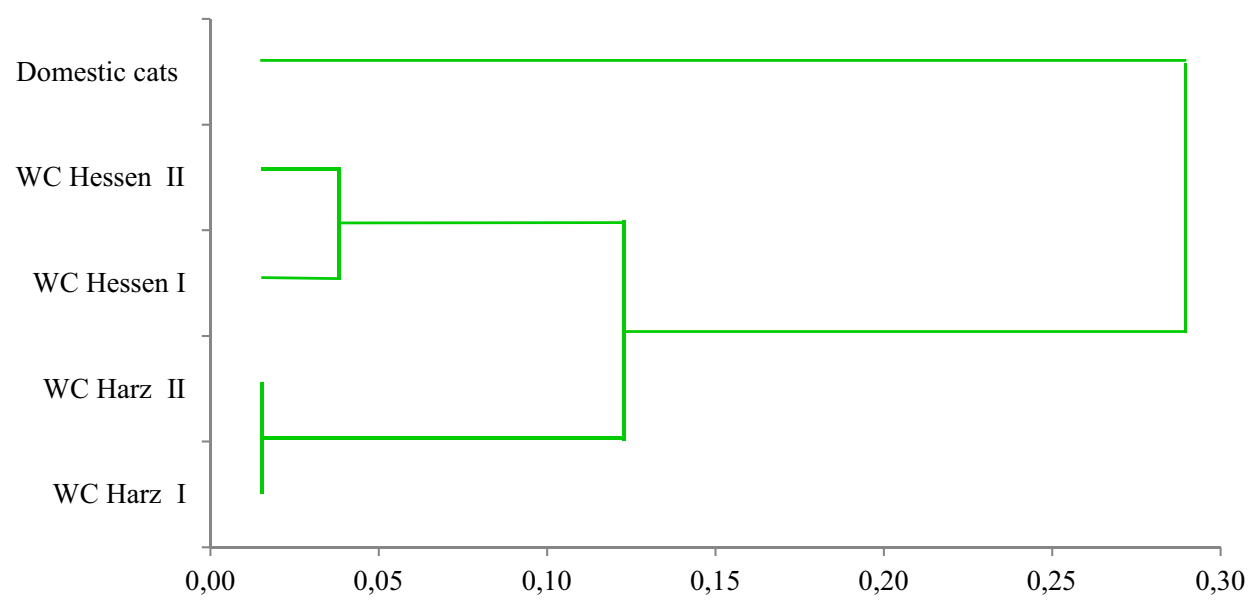

Table 6 Fluctuating asymmetry (FA) of the wildcats from Harz and Hesse as well as sub-groupings according to traffic infrastructure, time period and natural landscape and domestic cats

\begin{tabular}{llcr}
\hline Population & Subdivision & $\begin{array}{l}\text { Number of } \\
\text { individuals }\end{array}$ & FA [\%] \\
\hline Harz & & 76 & 13.32 \\
Hesse & & 64 & 9.82 \\
Domestic cats & & 71 & 19.04 \\
Total wildcats & & 140 & 11.74 \\
Harz I & West of B81 & 26 & 13.25 \\
Harz II & East of B81 & 50 & 13.39 \\
Hesse I & West of A7 & 41 & 10.52 \\
Hesse II & East of A7 & 23 & 8.47 \\
Harz $\mathrm{t}_{1}$ & 1942-1980 & 32 & 12.01 \\
Harz $\mathrm{t}_{2}$ & 1981-2018 & 44 & 14.21 \\
Harz $\mathrm{nl}_{1}$ & östliche Harzabdachung & 34 & 15.29 \\
Harz $\mathrm{nl}_{2}$ & Western Harz & 42 & 16.14 \\
\hline
\end{tabular}

lower range but comparative to other studies in this field (e.g., 11 characters for water shrews (Thier et al. 2019); 24 characters for Nyctereutes procyonoides (Ansorge et al. 2009), 40 for harbour porpoise, Phocoena phocoena (Gao and Gaskin 1996) and 70 characters in Przewalski's horses (Usukhjargal et al. 2020)). These examples clearly show that more foramina are considered in species when they have larger skulls. With the found correlation to sex and age in some traits, the number of actually analyzed ones was limited to 20 , still suitable for the size of cat skulls.

Non-metric trait variation is considered to be age and sex independent and traits are considered not inter-correlated (Corruccini 1976). This, however, has been addressed in several studies, for example, by Markowski (1995) and, therefore, traits with a statistically significant correlation to sex and age were eliminated here also. But in skulls under several developmental constraints every structure, including the foramina, are probably inter-correlated to some degree. However, no statistically significant inter-correlations were found using the $\chi^{2}$ test.

\section{Epigenetic variability}

The epigenetic variability of wildcats in the different samples ranges from 0.27 (Hesse I) to 0.40 (Harz I, see Table 2). The $I_{\mathrm{ev}}$ of the domestic cats is higher (0.48). These epigenetic variabilities of wildcats are within the range known from populations of some other Carnivora ranging from 0.17 for some populations of Nyctereutes procyonoides (Ansorge et al. 2009), to 0.32 for Mustela putorius, or 0.35 for Martes martes both in Saxony also (Ansorge 1992, 1994) and up to 0.45 in some samples of Meles meles (Eichstädt et al. 1997).

Both wildcat populations show a high degree of polymorphism and, therefore, using this indicator, no genetic depletion could be assumed. Molecular studies showed that the genetic diversity of wildcat populations in Germany is quite high despite of a possible bottleneck history and only smaller populations showed reduced genetic diversity (Eckert et al. 2010). The fact that the $I_{\mathrm{ev}}$ of the domestic cat is higher has probably two reasons: lumping all domestic cat skulls from across Germany to one group and domestication that lead to different breeds (even though many arose very recently). Williams (2007) emphasizes that domestic cats are a "walking gene pool". They were studied here for comparative reasons and not with the aim to assess the 'population status' of domestic cats particularly as free breeding and partner choice can be questioned.

The grouping according to the major traffic infrastructure shows differences in the $I_{\mathrm{ev}}$ between the populations in the Harz and in Hesse (Table 2). Although the findpoints of the cats in Hesse are much further apart, there is less variation, which would hint to lower genetic diversity. This is in accordance with the fact, that the Harz is 
less fragmented as only country roads transect it and so the animals have the opportunity to walk further distances easier. Country roads are generally easier to cross than highways (Hötzel et al. 2007). In Hesse, however, the animals are separated by the A7 motorway and according to Hupe et al. (2004), there are too few safe crossing structures. In addition, several individuals avoid using the same crossing aid.

The epigenetic variability for the Harz sub-samples of the two time periods are very close to each other $\left(I_{\mathrm{ev}}=0.37\right.$ and $I_{\mathrm{ev}}=0.36$ ) which does not indicate genetic depletion over time. However, a subdivision in finer scaled and shorter periods was not possible due to the resulting small sample sizes. Combining all skulls from a time period over 100 years to one overall sample might influence the result, but an unknown degree. The subdivision of the animals according to the natural landscapes shows differences in the $I_{\mathrm{ev}}$ : A slightly lower $I_{\mathrm{ev}}(0.34)$ was found in the area of the 'östliche Harzabdachung' than in the western Harz (Harz $\mathrm{nl}_{1}, I_{\mathrm{ev}}$ 0.40) which cannot be clearly explained and might be a natural random effect. The specimens grouped as Harz $\mathrm{nl}_{2}$ were found closer to each other and more likely represent a natural population with less migration than in Harz $\mathrm{nl}_{1}$. Additionally, the long time interval during which the studied skulls were collected might pose a problem here, as different aspects but those we selected for subgrouping might be relevant but go undetected.

\section{Epigenetic distances}

The MMD values between the groups for the Harz and Hesse are statistically significant, but not for their respective subgroups Hesse I and II, Harz I and II, nor Harz $\mathrm{nl}_{1}$ and Harz $\mathrm{nl}_{2}$. The MMD values for wildcats range from -0.0032 to 0.1144; those for domestic cats are larger (Tables 3, 4, 5). As assumed, wild and domestic cats have larger genetic distances to each other than different wildcat populations to each other (Fig. 3). For raccoon dogs in Germany MMD values that range between -0.01 and 0.40 were determined with distances up to 1.13 when European populations were compared to the native one in the Amursk region. It was considered "generally high, being at levels hardly found in any other mammalian species" (Ansorge et al. 2009). The MMDs for Eurasian otters from Europe and Kamchatka varied from 0.018 to 0.509 (Ranyuk and Ansorge 2015). Thus, the MMDs found here for wildcats for the sub-groupings are comparable to the MMDs for other species-considering the relative short geographic distances.

In future studies, it would be interesting to compare more different regional populations of wildcats, different wildcat subspecies and domestic cats.

\section{Fluctuating asymmetry}

The FA of the wildcats ranged between $9.82 \%$ in Hesse and $13.32 \%$ in the Harz (all specimens from each region considered). These relatively low values indicate high fitness and developmental stability of the populations assuming the often-hypothesized negative correlation of FA with heterozygosity and fitness and genetic variability. The FAs of the sub-groups differ but are all relatively low (Table 6). The largest asymmetries show the sub-groups Harz $\mathrm{nl}_{1}$ and $\mathrm{nl}_{2}$ (15.29\% and 16.14\%). Zachos et al. (2007) showed a fluctuation from 4.8 up to $67 \%$ between the different traits in roe deer (sample sizes from 16 to 26). For small mammals' asymmetries in non-metric characters of 14-44\% are assumed (Lazarová 1999), so that the observed values here are at the lower end to just below the known range.

The FA of metric and non-metric features is caused by different influences during ontogenesis (Pertoldi et al. 1997; Suchentrunk et al. 1998). Some authors assume it is due to features influencing the development during ontogenesis (Siegel and Doyle 1975). Others also assume genetic stress like inbreeding or hybridization as further cause (Parsons 1990) so that clear associations to individual factors are difficult. However, a study on an inbreed wolf population did not show an increased FA (Wiig and Bachmann 2014) so the assumption that inbreeding increases FA was not supported there.

In the common shrew, Sorex araneus, the level of developmental stability as estimated by FA highly correlates with population density-but only in cyclic populations. Also, a relation of FA and breeding success was found (Zakharov et al. 1991). These authors also noted difference in FA between the years. If this is a general issue, the cat samples studied here collected over many years might be influenced by such fluctuation. With species of which material in collections is limited, the forming of subpopulations on a yearly basis or at least of short time intervals is impossible.

FA in the sexual ornaments of males has also been used to indicate the quality of males, for example, by Møller (1990, 1991).

Due to the unclear causes of FA, for example, Lens et al. (2002) critically discuss FA. Zachos et al. (2007) have addressed the assumed negative correlation between FA and genetic variability and did not find statistically significant correlations between FA and genetic variability. However, they concluded, "the question of the genetic factors governing developmental stability is still far from being settled." (Zachos et al. 2007: p. 398). And more recently Beasley et al. (2013) consider the use of FA legitimate as marker of environmental stress. To discover for example, which genes play a role in the development of foramina would make it possible to untangle how much is 
caused by genes and what is due to developmental, environmental and other epigenetic influences.

\section{Individual foramina}

The study showed that there is no foramen to differentiate wild and domestic cats, fostering the short list of really diagnostic morphological features (Piechocki 1990; Stefen and Görner 2009). However, some differences in the frequency of the specificity of some foramina were observed: for example, the foramen alisphenoidalis ventralis (\#16) on the right side is double in $6.82 \%$ of wildcats but in $42.42 \%$ of domestic cats. This might be just a random effect, as the same foramen on the left side was double in $11.28 \%$ of wildcats and $36.36 \%$ of domestic cats which gives a less developed difference. The least differences in this respect between the wild and domestic cats were observed in the foramen opticum (\#17) and foramen incisivum (\#1) (see Table S2, S3).

It is known that wild and domestic cats hybridize to different degrees within the distribution range of wildcats in Europe (Pierpaoli et al. 2003). Despite of several studies on the distinction between wildcats, domestic cats and their hybrids, a morphological characterization of hybrids is not possible. This refers also to foramina, which do not even differ between wild and domestic cats. Whether-the relatively low-rate of hybridization in Central Germany (Krüger et al. 2009; Steyer et al. 2018) might affect epigenetic variability, distance or FA cannot be assessed (so far).

\section{Polymorphism in non-metric traits: epigenetic variation and genetics}

The study of non-metric characters like here is one approach to describe and understand variation in nature or biodiversity. For a long time mainly (morpho-) metric diversity was used and starting in about the 1930s and 1940s examples of genetic polymorphism were given (Berry and Searle 1963). These authors coined the term "epigenetic polymorphism" for "discontinuous variation, which is characterized by the fact that the discontinuity is not determined at fertilization but at some later stage in development". (Berry and Searle 1963: p. 578). There are, however, "genetic factors determining the main features of the "epigenetic landscape" (Berry and Searle 1963: p. 578). At that time not much was known about the connection of genotype and phenotype, and the interest to understand the underlying genetic causes for biodiversity manifested in different phenotypes of organisms and in particularly mammals closest to humans, is still of great interest. With the advances in genetics, moving to genomics in recent years, new methods arose to approach this question. Knowing, for example, which genes are playing a role in the development of foramina would make it possible to untangle how much is due to genes and what is due to developmental and other epigenetic influences. Shedding more light into that would also help to understand and assess for which aspects epigenetic variability and/or FA are indicative and how reliable their current use in the assessment of populations is. The use of the Forward Genomics approach (Hiller et al. 2012) currently aims at identifying target genes which play a role determining specific mammalian phenotypes like for instance the vomeronasal organ (Hecker et al. 2019a), loss of teeth, development of body armor in pangolins and armadillos (Sharma et al. 2018) or feeding preferences (Hecker et al. 2019b). Even though variability on the population level cannot be addressed in this way, it might help to contribute to the understanding of the genetic basis of individual foramina.

In association with cranial foramina there is one known variable ossification defect in humans-enlarged parietal foramina - which is known to be a "hereditary condition and genes associated with it have been identified" (Griessenauer et al. 2013: p. 543). Nevertheless, "information on genotype-phenotype correlations is incomplete" (Mavrogiannis et al. 2006).

\section{Conclusion}

The epigenetic variability for all wildcat groups were within the range known for other Carnivora, but at the lower middle range. These values still do not indicate severe genetic depletion for wildcats in the Harz and Hesse. Similarly, the low FA values are within the range known from other species and do indicate developmental stability. Neither the form nor presence or absence of the studied foramina nor their FA values are useful to differentiate wild and domestic cats.

Overall future advances in genetics and genomics will hopefully shed more light on the genetic and epigenetic basis of non-metric traits so that it can be better understood what epigenetic distance and FA really indicate and if their use in population assessment can be further warranted and more specified.

Supplementary Information The online version contains supplementary material available at https://doi.org/10.1007/s42991-021-00119-0.

Acknowledgements We thank Jens Jakobitz, Dresden, Dr. Karla Schneider, Halle, Diana Jeschke, Görlitz, Mike Heddergott, Heilbad Heiligenstadt and Dr. Franz Müller, Fulda, for the procurement and provision of the skulls. Special thanks also go to Prof. Dr. Hermann Ansorge and Paul Lippitsch, both Görlitz, for the introduction to the methodology. Markward Fischer, Dresden, helped with the figures. The text was proofread by Romy Adler, MD, MSc. The study was financially supported by the Leibniz Association, SAW-2016-SGN-2. The helpful comments of the reviewers which improved the text are thankfully acknowledged. 
Author contributions LL conducted study and drafted the manuscript, CS initiated the study and finalized the manuscript, co-author of application for funding.

Funding Open Access funding enabled and organized by Projekt DEAL.. Financially supported by Leibniz Association, SAW-2016-SGN-2.

Data availability List of material and results are in electronic supplementary data.

\section{Declarations}

Conflict of interest The authors declare that they have no conflict of interest.

Ethical approval Only material stored in collections was used.

Consent to participate Both authors agree on participation.

Consent for publication Both authors agree on publication.

Open Access This article is licensed under a Creative Commons Attribution 4.0 International License, which permits use, sharing, adaptation, distribution and reproduction in any medium or format, as long as you give appropriate credit to the original author(s) and the source, provide a link to the Creative Commons licence, and indicate if changes were made. The images or other third party material in this article are included in the article's Creative Commons licence, unless indicated otherwise in a credit line to the material. If material is not included in the article's Creative Commons licence and your intended use is not permitted by statutory regulation or exceeds the permitted use, you will need to obtain permission directly from the copyright holder. To view a copy of this licence, visit http://creativecommons.org/licenses/by/4.0/.

\section{References}

Ansorge H (1992) Craniometric variation and nonmetric skull divergence between populations of the pine marten, Martes martes. Abh Ber Naturkdmus Görlitz 66:9-24

Ansorge H (1994) Verbreitung und Biologie des Iltis, Mustela putorius, in der Oberlausitz. Abh Ber Naturkdmus Görlitz 68:1-16

Ansorge H (2001) Assessing non-metric skeleton characters as a morphological tool. Zoology 104:268-277

Ansorge H, Stubbe M (1992) Populationsdifferenzierung beim Fischotter Lutra lutra (L.) nach non-metrischen Schädelmerkmalen. Semiaquatische Säugetiere Wiss Beit Univ Halle 1992:401-415

Ansorge H, Stubbe M (1995) Nonmetric skull divergence in the otter - assessing genetic insulation of populations. IUCN Otter Spec Group Bull 11:15-24

Ansorge H, Ranyuk M, Kauhala K, Kowalczyk R, Stier N (2009) Raccoon dog, Nyctereutes procyonoides, populations in the area of origin and in colonised regions - the epigenetic variability of an immigrant. Ann Zool Fenn 46:51-62

Ansorge H, Anděra M, Borkenhagen P, Büchner S, Juškaitis R, Markov G (2012) Morphological approach to the genetic variability of the common dourmouse Muscardinus avellanarius. Peckiana $8: 265-274$

Bauchau V (1988) Non-metrical variation in wild mammals: a bibliography. Mamm Rev 18(4):195-200
Berry RJ (1963) Epigenetic polymorphism in wild populations of Mus musculus. Genet Res 4(2):193-220

Berry AC (1975) Factors affecting the incidence of non-metrical skeletal variants. J Anat 120:519

Berry AC, Berry RJ (1967) Epigenetic variation in the human cranium. J Anat 101:361

Berry RJ, Searle AG (1963) Epigenetic polymorphism of the rodent skeleton. Proc Zool Soc Lond 140(4):577-615

Clutton-Brok J (1999) A natural history of domesticated mammals. Cambridge University Press, Cambridge

Corruccini RS (1976) The interaction between nonmetric and metric cranial variation. Am J Phys Anthropol 44:285-293

De Beasley AE, Bonisoli-Alquati A, Mousseau TA (2013) The use of fluctuating asymmetry as a measure of environmentally induced developmental instability: a meta-analysis. Ecol Indic 30:218-226

Driscoll CA, Menotti-Raymond M, Roca AL, Hupe K, Johnson WE, Geffen E, Harley EH, Delibes M, Pontier D, Kitchener AC, Yamaguchi N, O'Brien SJ, Macdonald DW (2007) The Near Eastern origin of cat domestication. Science 317(5837):19-523

Driscoll CA, Clutton-Brock J, Kitchener AC, O'Brien SJ (2009) The taming of the cat. Sci Am 300:68-75

Eckert I, Suchentrunk F, Markov G, Hartl GB (2010) Genetic diversity and integrity of German wildcat (Felis silvestris) populations as revealed by microsatellites, allozymes, and mitochondrial DNA sequences. Mamm Biol 75:160-174

Eichstädt H, Ansorge H, Hofmann T, Stubbe M (1997) Populationsdifferenzierung beim Dachs - epigenetische Unterscheidung. Ber Natforsch Ges Oberlausitz 6(suppl): 11

Gao A, Gaskin DE (1996) Nonmetric morphometry of the skull of the harbour porpoise, Phocoena phocoena, in the western North Atlantic and eastern North Pacific. Can J Zool 74:2199-2205

Griessenauer CJ, Veith P, Mortazavi MM, Stewart C, Grochowsky A, Loukas M, Tubbs RS (2013) Enlarged parietal foramina: a review of genetics, prognosis, radiology, and treatment. Childs Nerv Syst 29(4):543-547

Grünberg H (1952) Genetical studies on the skeleton of the mouse. IV. Quasi-continuous variations. J Genet 51:95

Hecker N, Lächele U, Stuckas H, Giere P, Hiller M (2019a) Convergent vomeronasal system reduction in mammals coincides with convergent losses of calcium signalling and odorant-degrading genes. Mol Ecol 28(16):3656-3668

Hecker N, Sharma V, Hiller M (2019b) Convergent gene losses illuminate metabolic and physiological changes in herbivores and carnivores. Proc Natl Acad Sci USA 116(8):3036-3041

Hilborn R (1974) Inheritance of skeletal polymorphism in Microtus californicus. Heredity 33(1):87-89

Hiller M, Schaar BT, Indjeian VB, Kingsley DM, Hagey LR, Bejerano G (2012) A "forward genomics" approach links genotype to phenotype using independent phenotypic losses among related species. Cell Rep 2(4):817-823

Hötzel M, Klar N, Schröder S, Steffen C, Thiel C (2007) Die Wildkatze in der Eifel - Habitate, Ressourcen, Streifgebiete. Ökologie der Säugetiere 5, Laurenti-Verlag, Bielefeld

Hupe K, Pott-Dörfer B, Götz M (2004) Nutzung autobahnnaher Habitate im Bereich der BAB 7 nördlich von Seesen durch die europäische Wildkatze (Felis silvestris silvestris) unter dem Aspekt der Lebensraumzerschneidung. Inf Natschutz Niedersachsen 4:266-278

Kitchener A (1991) The natural history of the wild cats. Cornell University Press, New York

Kitchener AC, Breitenmoser-Würsten Ch, Eizirik E, Gentry A, Werdelin L, Wilting A, Yamaguchi N, Abramov AV, Christiansen P, Driscoll C, Duckworth JW, Johnson W, Luo SJ, Meijaard E, O’Donoghue P, Sanderson J, Seymour K, Bruford M, Groves C, Hoffmann M, Nowell K, Timmons Z, Tobe S (2017) A revised taxonomy of the Felidae. The final report of the Cat 
Classification Task Force of the IUCN/ SSC Cat Specialist Group. Cat News Special Issue 11

Korkhaus G (1930) Anthropologic and odontologic studies of twins. Int J Orthod Oral Surg Radiogr 16(6):640-647

Krüger M, Hertwig ST, Jetschke G, Fischer MS (2009) Evaluation of anatomical characters and the question of hybridization with domestic cats in the wildcat population of Thuringia, Germany. J Zool Syst Evol Res 47(3):268-282

Lazarová J (1999) Epigenetic variation and fluctuating asymmetry of the house mouse (Mus) in the Czech Republik. Folia Zool 48(1 suppl.):37-52

Lens L, Van Dongen S, Kark S, Mattheysen E (2002) Fluctuating asymmetry as an indicator of fitness: can we bridge the gap between studies. Biol Rev 77:27-38

Lkhagvasuren D, Batsaikhan N, Samiya R, Schafberg R, Stubbe A, Stubbe M, Ansorge H (2015) Morphological approach to genetic variability of the Asiatic Wild Ass (Equus hemionus) using non-metric skull characters. Mong J Biol Sci 13:3-12

Markowski J (1995) Non-metric traits: remarks on sex dependence, age dependence, and on intercorrelations among characters. Acta Theriol 40:65-74

Mavrogiannis LA, Taylor IB, Davies SJ, Ramos FJ, Olivares JL, Wilkie AO (2006) Enlarged parietal foramina caused by mutations in the homeobox genes ALX4 and MSX2: from genotype to phenotype. Eur J Hum Genet 14:151-158

Møller AP (1990) Fluctuating asymmetry in male sexual ornaments may reveal male quality. Mamm Rev 5:121-172

Møller AP (1991) Sexual ornament size and the cost of fluctuating asymmetry. Proc R Soc Lond B Biol Sci 243(1306):59-62

Palmer AR, Strobeck C (1986) Fluctuating asymmetry: measurement, analysis, patterns. Annu Rev Ecol Syst 17:391-421

Palmer AR, Strobeck C (2003) Fluctuating asymmetry analyses revisited. In: Polak M (ed) Developmental instability: causes and consequences. Oxford University Press, Oxford, pp 279-319

Parsons PA (1990) Fluctuating asymmetry: an epigenetic measure of stress. Biol Rev Camb Philos Soc 65(2):131-145

Pertoldi C, Loeschcke V, Madsen A, Randi E (1997) Developmental stability in the Eurasian Otter (Lutra lutra) in Denmark. Ann Zool Fenn 34:187-196

Pertoldi C, Madsen A, Randi E, Braun A, Loeschcke V (1998) Variation of skull morphometry of Eurasian otters Lutra lutra in Denmark and Germany. Ann Zool Fenn 35:87-94

Piechocki R (1990) Die Wildkatze - Felis silvestris. Die neue BrehmBücherei, 189, Ziemsen, Wittenberg Lutherstadt

Pierpaoli M, Biro ZS, Randi E et al (2003) Genetic distinction of wildcat (Felis silvestris) populations in Europe, and hybridization with domestic cats in Hungary. Mol Ecol 12(10):2585-2598

Ranyuk M, Ansorge H (2015) Low epigenetic variability of the Eurasian otter Lutra lutra (L.) from Europe to Kamchatka. Russ J Ecol 46:195-201

Ranyuk M, Monakhov VG (2016) A comparative analysis of craniological variability of Eurasian (Sable and Pine Marten) and North American (American Marten) species of the Martes genus. Biol Bull 43:893-903

Santos F (2018) AnthropMMD: an R package with a graphical user interface for the mean measure of divergence. Am J Phys Anthropol 165:200-205

Serpell JA (1988) The domestication and history of the cat. In: Turner DC, Bateson P (eds) The domestic cat. The biology of its behaviour. Cambridge University Press, Cambridge, pp 151-158

Sharma V, Hecker N, Roscito JG, Foerster L, Langer BE, Hiller M (2018) A genomics approach reveals insights into the importance of gene losses for mammalian adaptations. Nat Commun 9(1):1-9

Siegel MI, Doyle WJ (1975) The effects of cold stress on fluctuating asymmetry in the dentition of the mouse. J Exp Zool 193(3):385-389
Sjøvold T (1977) Non-metrical divergence between skeletal populations - the theoretical foundation and biological importance of C.A.B, Smith's Mean Measure of Divergence, Osteological Research Laboratory. University of Stockholm, Solna

Smith M (1981) Relationship between genetic variability and niche dimensions among coexisting species of Peromyscus. J Mamm 62:273-285

Stefen C, Görner M (2009) Die Wildkatze (Felis silvestris Schreber, 1777) in Deutschland und Mitteleuropa - zum Stand der Forschung und Konsequenzen für den Schutz. Säugetierkd Inf 7(38):3-216

Stefen C, Heidecke D (2011) Kraniometrische Variabilität der Wildkatze (Felis silvestris Schreber, 1777) im Harzgebiet. Hercynia 44:253-285

Stefen C, Heidecke D (2012) Ontogenetic changes in the skull of the European wild cat (Felis silvestris Schreber, 1777). Vert Zool 62(2):281-294

Steyer K, Kraus RHS, Mölich T, Anders O, Cocchiararo B, Frosch C, Geib A, Götz M, Herrmann M, Hupe K, Kohnen A, Krüger M, Müller F, Pir JB, Reiners TE, Roch S, Schade U, Schiefenhövel P, Siemund M, Simon O, Steeb S, Streif S, Streit B, Thein J, Tiesmeyer A, Trinzen M, Vogel B, Nowak C (2016) Large-scale genetic census of an elusive carnivore, the European wildcat (Felis s. silvestris). Conserv Genet 17:1183-1199

Steyer K, Tiesmeyer A, Muñoz FV, Nowak C (2018) Low rates of hybridization between European wildcats and domestic cats in a human dominated landscape. Ecol Evol 8(4):2290-2304

Suchentrunk F, Hartl GB, Flux JEC, Parkes J, Haiden A, Tapper S (1998) Allozyme heterozygosity and fluctuating asymmetry in brown hares Lepus europaeus introduced to New Zealand - Developmental homeostasis in populations with a bottleneck history. Acta Theriol 43:35-52

Swaddle JP, Witter MS, Cuthill IC (1994) The analysis of fluctuating asymmetry. Anim Behav 48(4):986-989

Thier N, Ansorge H, Stefen C (2019) Assessing geographic differences in skulls of Neomys fodiens and Neomys anomalus using linear measurements, geometric morphometrics and non-metric epigenetics. Mamm Res. https://doi.org/10.1007/s13364-019-00448-z

Usukhjargal D, Schafberg R, Sablin MV, Ganbaatar O, Ansorge H (2020) Epigenetic variability of the highly endangered Przewalski's Horses in temporal and geographical populations. Mong J Biol Sci 18:31-40

Weber E (1980) Grundriß der Biologischen Statistik. Fischer Verlag, Jena Wiig Ø, Andersen T (1988) Non-metrical variation in the skull of Norwegian Lynx. Acta Theriol 33:3-19

Wiig Ø, Bachmann L (2014) Fluctuating asymmetry and inbreeding in Scandinavian gray wolves (Canis lupus). Acta Theriol 59:399-405

Wiig Ø, Lie RW (1979) Metrical and nonmetrical skull variations in Norwegian Wild Mink (Mustela vison Schreber). Zool Scr 8:297-300

Williams E (2007) Katzenrassen - Geschichte, Bilder, Fakten. Parragon Books Ltd, Bath

Wozencraft WC (1993) Order carnivora. In: Wilson DE (ed) Mammal species of the world. A taxonomic and geographic reference. Smithsonian Institution Press, pp 279-348

Zachos F, Hartl G, Suchentrunk F (2007) Fluctuating asymmetry and genetic variability in the roe deer (Capreolus capreolus) - a test of the developmental stability hypothesis in mammals using neutral molecular markers. Heredity 98:392-400

Zakharov VM, Pankakoski E, Sheftel BI, Peltonen A, Hanski I (1991) Developmental stability and population dynamics in the common shrew, Sorex araneus. Am Nat 138(4):797-810

Publisher's Note Springer Nature remains neutral with regard to jurisdictional claims in published maps and institutional affiliations. 